\title{
Earthquake makes waves for tsunami models
}

\section{David Cyranoski, Tokyo}

Researchers investigating how tsunamis form are awash with data following an earthquake in Japan late last month.

The quake, which had a magnitude of 8.0, struck off the southeastern shore of the northern island of Hokkaido on 26 September, sending waves up to four metres tall rushing towards the coast. But the quake's epicentre was almost directly beneath an ocean-bottom monitoring system, containing instruments that use pressure gauges to measure rises and dips in the ocean floor.

Scientists are now rushing to plug the data from these instruments into models of tsunami generation, which they say should help them to improve predictions of the waves and perhaps prevent future fatalities.

Tsunamis - waves that can reach up to 30 metres high - are created by sudden jolts to the sea floor. Although instruments have monitored passing tsunamis before, they have never collected data from the spot where such a wave is born, says Kiyoshi Suyehiro, director of the deep-sea-research department at the Japan Marine Science and Technology Center in Yokosuka. These data have been the missing link to understanding tsunami generation, he says. "We now have actual data to test models that incorporate the earthquake faulting, resulting sea-bottom deformation, and responding seawater mass movement," says Suyehiro.

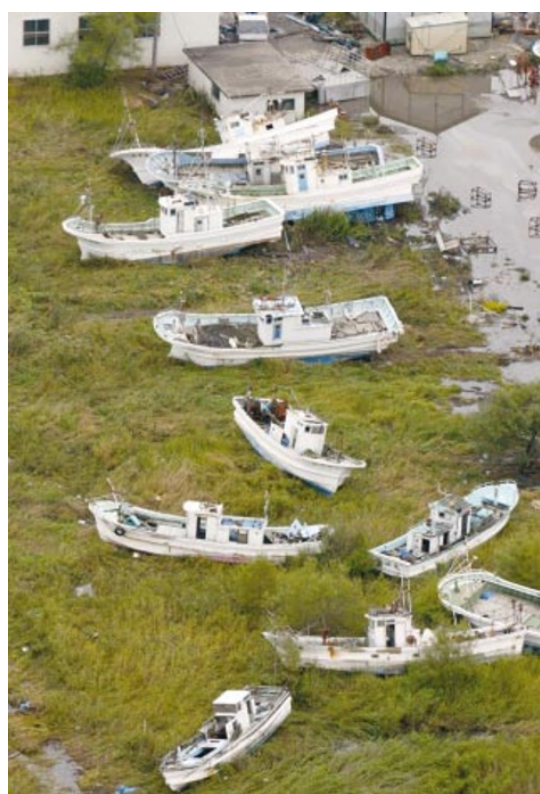

After the storm: Japanese fishing boats languish on the shore following last month's tsunami.

That should help to make tsunami warnings more accurate. Such alerts are already common in earthquake-prone Japan, where seismic waves travelling at 20,000 kilometres per hour are used to predict the arrival of tsunamis, which travel at a mere $750 \mathrm{~km}$ per hour. But those predictions are based on a fairly simple model and are often wrong, says Kenji Satake, an earthquake researcher at the National Institute of Advanced Industrial Science and Technology in Tsukuba, Japan. The tsunami from the September quake, for example, was twice as high as predicted by the Japan Meteorological Agency.

"Basically a big earthquake is taken to mean a big tsunami," says Satake. But that is not always the case. Some tsunamis are caused by mild earthquakes that pack a bigger punch in terms of making waves. This phenomenon isn't fully understood, but is thought to depend on factors such as the direction and speed of the seafloor slip along the fault.

Researchers still need to clean up the data from the recent quake, to adjust for the effect of water temperature on the measurements, for example. "Once that is done, they can be used to understand the dynamics of tsunami generation," says Satake. Suyehiro is already racing to apply the data to his own model. "We're working as fast as we can," he says.

Others, such as Charles Sollitt, an emeritus civil engineer at Oregon State University's Wave Research Laboratory in Corvallis, will use the data to study how far, and how fast, tsunamis can flood over the coastline. But Harry Yeh, a tsunami expert at Oregon State University, notes that progress might be slowed by the fact that a lot of the information posted online about the data is written only in Japanese.

\section{Bleak forecast for space weather}

\section{Tony Reichhardt, Washington}

The main US centre for predicting and monitoring solar storms could be shut down unless government agencies and other users of 'space weather' forecasts rally to its defence, according to scientists and congressional staff.

The Space Environment Center (SEC) of the National Oceanic and Atmospheric Administration (NOAA) in Boulder, Colorado, has had its \$8.3-million funding request for 2004 rejected by the Senate subcommittee that determines appropriations to the US Department of Commerce, of which NOAA is a part. The subcommittee proposes cutting off the SEC's funding completely.

The House of Representatives' bill cuts the request by $40 \%$, which would save the centre but cause "serious downsizing", according to the SEC's deputy director, Ron Zwickl.

The House and Senate bills will be reconciled within the next few weeks. The final appropriation is typically somewhere between the two figures, but in rare cases the full funding request can be restored.
The SEC is the primary US source of solar-activity forecasts, which are generated from satellite data and readings from ground-based solar telescopes and geomagnetic sensors. Because intense solar flares can harm equipment ranging from satellites in space to electrical power grids on the ground, the SEC's alerts go to a wide variety of customers, including NASA, the Pentagon, utility companies and airlines.

The congressional committees think that the public agencies should be paying for the data that they use. "If somebody really wants it badly enough in a tight budget environment, they need to step up to the plate," says Kevin Linskey of the Senate appropriations committee staff.

But the SEC's supporters, including Daniel Baker, director of the Laboratory for Atmospheric and Space Physics at the nearby University of Colorado, counter that NASA has traditionally been opposed to paying for monitoring networks. And the US Air Force, which uses the SEC's data to create its own space-weather forecasts,

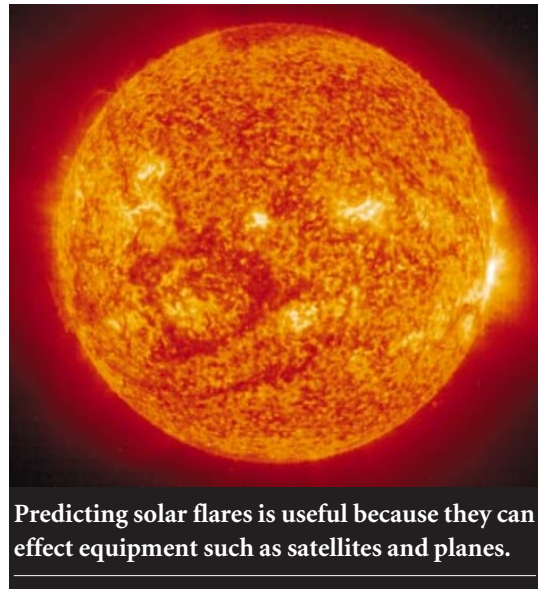

has not volunteered to fund the centre.

The American Astronomical Society has written letters of support and alerted its members to the SEC's plight. Advancedtechnology company Lockheed Martin, United Airlines and several US utility firms have weighed in to defend the centre. Some NOAA officials hope that the centre could be saved by incorporating it into the agency's National Weather Service, or that the final bill will restore the funding. 